\title{
Research and Design to the Training Model of High-tech Arms Talents
}

\author{
Qing SUN1,a,", Dongyan SUN² and Yanhong LIN³ \\ 1,2,3Air Force Engineering University, Xi'an, China \\ aEmail: sunqing2002@126.com
}

\begin{abstract}
Keywords: Training mode, Commanding and technology integration, Teaching Course System, Competence quality platform.
\end{abstract}

\begin{abstract}
Focusing on the requirement of talent training in military troops, and combining with the present situation of the talent cultivation in military academy and the growth reality of the high-tech Arms, the paper points out the training goal to the talent knowing both technology and command, and constructs the curriculum teaching system of theory, experiment and practice which support and permeate with each other, builds a competence and quality platform integrated knowledge, ability and quality, and demonstrates the supporting conditions and system protection. The research may provide strong theoretical support and clear practice path to the talent training work.
\end{abstract}

\section{Introduction}

In recent years, the progress of military science and technology has made the unprecedented changes in the equipment form, system composition and combat training of high-tech Arms, and the information war has become the main form of high-tech Arms fighting. The increasingly rich elements of knowledge in war lead to the war that high-tech Arms facing has become a fierce confrontation between the usage of intelligent and the materialization of research. The technical contents of the weapons and equipments are getting higher and higher, but the main body of the war is still the confrontation among persons.

At present, the upgrades of equipments in high-tech military units and institutions of education reform in military academies promote each other, which has improved the quality of personnel training significantly. Meanwhile, it should be seen that new technologies and equipments have widen the gap between persons and equipments. The changes in the form of combat have also constantly refreshed the definition of talent. We must research the relationship among the factors of combat elements and find out the law of talent training to meet the urgent requirement for high-tech Arms to enhance combat effectiveness based on its training practice.

\section{Research ideas and training target}

Following the characteristics of military higher education and the growth of military officers, and focusing on the future development of new equipment and the new requirements in personnel knowledge, ability and quality from integration operations of air and space, and in accordance with the general principle of "thick foundation, strong military and fine skills", we should consolidate the basis of general education, strengthen the training of vocational skills and pay attention to the development of individuality to cultivate a new type of military talent who knows both command and technology.

We should take ability training as the core, adhere to integrate the general education and professional education closely, build common cognitive platform for command and professional technical personnel, and train compound elite talent who will be comprehensive development with moral, intellectual, military and physical, adapt to the needs of military information construction, possess firm ideals and beliefs, excellent military foundations and military professional skills, wide humanities and social sciences, natural science and engineering technology foundation, good military temperament, physical quality and psychological quality, strong innovation and command and management ability, superior overall quality and development potential, which means one should 
know technology, management skills and command simultaneously. Students will grow up to the professional and technical backbone, and gradually grow into technical experts and leaders of future army building through practical training.

\section{Teaching Course System Design}

The teaching course system of commanding with technology combined training mode should be constructed scientifically from the three aspects of theory curriculum, experiment and practice in accordance with the development trend of general education, and the characteristics and standards of knowledge, ability and quality of high-tech Arms .

\subsection{Theoretical teaching curriculum system}

In the system, the theoretical teaching curriculum platform should be built to consolidate the basic knowledge of general education interrelated with subject foundation, professional direction and pre-job positions study so as to ensure the common requirements of the main categories in subject from the aspects of basic disciplines and comprehensive development, and to achieve organic convergence among general education, professional education and vocational education.

The theoretical teaching curriculum system is designed as the form of "platform \&module". The platform includes general education, subject foundation, professional direction, post service and so on.

The general education platform includes six modules such as political theory, military common foundation, leadership management foundation, humanities and social sciences, natural science and public tools.

The subject foundation platform includes four modules, mechanical engineering series, electronic engineering series, information technology series and control engineering series. According to the disciplines, the courses are divided into mechanical, electrical, electronic and information categories to make the students understand the basic knowledge and initially grasp the ability of analyzing and solving problems in the subject area.

The professional direction platform includes three modules, core base courses, general principle courses of equipment, job practice courses and so on. Through the training, students will master the basic skills of the discipline, initially possess professional skills in the field of expertise, adapt to the need of equipment development and job conversion, have a strong ability to ask questions and solve problems, and even possess the initial capacity to carry out professional research.

The post service platform includes three modules such as the post basis, post positions and serving expand. Courses of professional theory, military applications and practical training closely related to the post should be processed to make students know more about the basic theory and knowledge of combating and training, be familiar with the professional post operational principles, combat characteristics and the outline of training and assessment, systematically master the basic theory of military equipment command and combat application methods, master the organization and implementation methods of Arms training, the basic methods of grass-roots management, the military physical skills for professional needs, and adapt to the development of military equipment and post positions conversion with strong career development potential.

\subsection{Experimental teaching curriculum system}

Focusing on the training of students' personality development, experimental teaching platform should be built cultivated knowledge validation and innovation ability training. The experimental teaching curriculum system should be planned and designed from shallow to deep, from single to comprehensive, and from verification to research, meanwhile, the ideas of experiments design and research should be penetrated, so that students will be active in designing and comprehensive studying from the passive imitation.

In order to improve the quality of curriculum experiment teaching, the basic experiment, comprehensive design experiment and the innovative experimental project are set legitimately based 
on the characteristics of general education, subject foundation, professional orientation and post service platform. The experimental courses of general education platform and subject foundation platform will mainly set up basic experimental projects, with highlighting deep understanding and mastering the basic theory and professional basic theory. Experimental courses of professional direction platform will mainly set up research and innovative experimental projects to focus on the students' innovate ability training and the mastery of their own courses, as well as the relevant theoretical knowledge of the course. Experimental courses of post service platform will mainly set up comprehensive experimental projects to strengthen the students' understanding on high-tech equipment combat process, the mastery of professional theoretical knowledge and the improvement of service ability. The contents of experimental teaching not only focus on close contact with scientific research, engineering and social application practice, but also integrate the results of equipment development, technological innovation and experimental teaching reform, so as to ensure the constant update of experimental projects.

\subsection{Practical teaching curriculum system}

To strengthen the service skills training, practical teaching curriculum system should be progressively compounded with simulated basic operation, systematical real operation, networked confrontation training and based environmental experience, and through which, the students' post capacity will be improved effectively.

The system confrontation platform will be built to promote the networked confrontation training from single Arms to multi-Arms cooperation based on the interconnection of high-tech simulation equipments, integration of simulation equipments and virtual training system, and collocation of simulation equipment and the actual equipment. The construction of future battlefield environment, closing to the combat mission and opponents, will supply different roles from the commander to various positions for the trained students, and strengthen the operational training direction and effectiveness, and even further deepen the post ability.

Military academies should establish a practical operation and training base in the high-tech Arms, scientifically formulate training programs for students to adapt to the base environment, and define the purpose of training, tasks, time schedule, organization and implementation measures, management responsibilities and other issues. Students can be arranged into the army to build the class shift and be strict accordance with the troops to eat and live together, so that students can understand and be familiar with the troops all-round and multi-level from the aspects of daily develop, organization management, military training, equipment support and other implementation processes and methods, and the comprehensive ability and quality of students will be enhanced effectively simultaneously.

\section{Competence quality platform design}

In accordance with the principle of "combining theory with practice, penetration teaching with research, complementary class with the extracurricular, and converging school with outside", we should build a cognitive education platform, an ability innovation platform and a quality development platform for students' improvement on knowledge, ability and quality.

\subsection{The Cognitive Education Platform}

According to the knowledge integration requirements of talents with command and technology for military high-tech Arms, we should distinguish academic education stage and pre-job training stage, build mutual convergence and progressive general education platform, subject foundation platform, professional direction platform and post service platform.

The general education platform is composed of political theory module, military common foundation module, leadership management foundation module, humanities and social sciences module, natural science module and public tools module. The subject foundation platform consists of four modules such as mechanical engineering series course, electronic engineering series course, 
information technology series course, control engineering series course and so on. The professional direction platform includes modules such as the core basic course, general principles of equipments course, and the practice of practical skills. The post service platform consists of the basis of office module, post positions module and service expansion module.

\subsection{The capacity of innovating platform}

The capacity of innovating platform focuses on the promotion of students' innovative thinking, innovative character, knowledge structure and practical skills. Practical skills are the skills and ability to innovate the creative activities of the main body. Innovative thinking is the core, innovative character is the driving force, knowledge structure is the foundation, and practical skill is the means. The capability of innovating platform is designed by adopting three combinations, the combination of the first class and the second one, the combination of teaching and scientific research, and the combination of education and training and the environment.

\subsection{Quality development platform}

Quality development platform focuses on the training of political beliefs, scientific literacy, cultural literacy, military basic quality, physical quality psychological quality and so on. Quality development platform will be designed by enriching the education and training program continuously, by highlighting the second classroom training channels, and by focusing on the development of individual characteristics.

\section{Conclusion}

The usage of high-tech will not do without human and equipment, and the energy of equipment will be fully released relying on the best combination of people and equipments. Exponential development of equipment technology urgently needs institutions and personnel training institutions at all levels to seriously study the characteristics of Arms and the winning mechanism of high-tech war, grasp the direction and goal of personnel training, overall plan training of command talent and the technical one, and take transporting high-quality personnel and the improvement to the combat effectiveness of high-tech Arms as an important direction for the reform of personnel training model. Meanwhile, quality assurance conditions and mechanism guarantee of personnel training such as supporting policy, teaching mode reform, teaching conditions construction and mechanisms for motivating students should be processed to assure the training.

\section{References}

[1] Ma Xianwei, Zhang Li. Investigating on the new teaching mode of the open experiment according to the students' innovation ability, China Modern Educational Equipment 2011.05

[2] WU Chao-jian, TANG Juping. On the Construction of Open Experimental Teaching System Journal of Hunan Institute of Engineering, Social Science Edition), 2007.02.

[3] WU Mengjin. Plan to Promote the Development of Talent Science in the Army-Some Experience in Studying the Outline of the Talent Development Plan before 2020, theoretical studies on PLA Works.2011.02. 